\title{
PERLINDUNGAN HUKUM DAN ANALISIS POTENSI DESAIN INDUSTRI PADA EKONOMI KREATIF YANG BERBASIS ILMU PENGETAHUAN YANG DIHASILKAN OLEH UMKM DI KOTA PANGKALPINANG
}

\author{
Oleh: \\ Sigit Nugroho, S.H., M.H. \\ c_git_tik@yahoo.com \\ Sujadmi, S.Sos., M.A. \\ sujad.m13@gmail.com
}

\begin{abstract}
Businesses creativity is needed in maintaining Indonesia's economy, especially in the field of industrial design, so that the resulting industrial design businesses in Indonesia can be protected. One measure that can boost the economy of a region is how much the intellectual property to protected and developed as a defense of wealth and the economy of a region or nation. The purpose this research is to analyze the legal protection and the potential for industrial design in the creative economy in Pangkalpinang. This research, using qualitative research with descriptive research strategy (descriptive research). Object in this research regarding legal protection and the potential for industrial design in the creative economy. From this research can be generated that design in the creative economy in Pangkalpinang not many. The resulting designs are still not adequately protected. Industrial designs in Pangkalpinang still have the potential to be featured as one proponent of the community's economy, especially in Pangkalpinang.
\end{abstract}

Keywords: protection, potention, design, industry

\section{A. PENDAHULUAN}

Menyambut Masyarakat Ekonomi ASEAN (MEA) perlu ada persiapan yang matang dari negara Indonesia. Khususnya di dunia usaha, para pengusaha akan mengalami persaingan usaha yang semakin komplek, sehingga dimungkinkan akan terjadi persaingan usaha yang tidak sehat yang terjadi antar pengusaha lokal maupun asing. Kesadaran tentang pentingnya memperhatikan kesiapan MEA 2015 adalah kewajiban utama, karena jika tidak diantisipasi dan tidak dipersiapkan, maka MEA 2015 berpotensi menciptakan instabilitas terhadap perekonomian nasional, bahkan dapat merupakan ajang pencaplokan aset-aset ekonomi penting milik negara. ${ }^{1}$

\footnotetext{
1 Otjih Sewandarijatun, Siapkah kita Menghadapi Masyarakat Ekonomi Asean, http://leuserantara.com/artikel-siapkah-kitamenghadapi-masyarakat-ekonomi-asean-mea-2015/ diakses tanggal 16 April 2015.
} 
Perlu juga diperhatikan, bahwa persaingan usaha nantinya akan berpengaruh pada UMKM. Jika produk UMKM tidak dapat bersaing dengan produk luar dan tidak mempunyai nilai lebih dapat tersingkirkan.

UMKM di setiap daerah di Indonesia harus dipersiapkan untuk menghadapi MEA yang berlaku secara efektif akhir 2015. Persiapan yang harus dilakukan pemerintah melalui dua bentuk yaitu perundang-udangan yang dapat melindungi pengusaha-pengusaha Indonesia dan juga kemampuan dari pengusaha untuk mengembangkan produk yang berkualitas berbasis pengetahuan, sehingga produk tersebut akan dapat dikembangkan dan dilindungi secara baik dan efektif. Peraturan perundang-undangan memberikan perlindungan yang efektif terhadap produk berbasis pengetahuan yang dihasilkan oleh UMKM terhadap berbagai bentuk penjiplakan, pembajakan atau peniruan ${ }^{2}$ atas produknya oleh pihak yang tidak bertanggung jawab yang dapat menyebabkan kerugian bagi pelaku usaha. Hal tersebut dapat terjadi bila perlindungan terhadap produk tidak baik dan hal tersebut

2 Sudargo Gautama dan Rizawanto Winata, Hak atas Kekayaan Intelektual (HAKI)Peraturan Baru Desain Industri, Cetakan Kedua yang Direvisi dan Ditambah, Citra Aditya Bakti, Bandung, 2004, Hlm. 10. harus ada tindakan aktif dari pelaku usaha untuk melindungi produknya (hasil karyanya). Untuk pembuatan produk yang berkualitas memang suatu keharusan bagi pelaku usaha seperti yang telah ditentukan dalam Undang-Undang Perlindungan Konsumen. Akan tetapi, untuk mempertahankan keberlangsungan usahanya bukan hanya kualitas produk yang terus dijaga, akan tetapi juga perlu adanya kreatifitas untuk menciptakan produk-produk baru yang lebih bermanfaat dan menarik bagi konsumen. Sehingga keberlangsungan usahanya akan tetap dapat dipertahankan dan dapat bersaing dengan para pelaku usaha asing yang produknya beredar dan bersaing di Indonesia. Kedua bentuk persiapan tersebut menjadi sebuah kajian kekayaan intelektual dan perlindungan haknya.

Bila kita melihat lebih jauh mengenai perekonomian suatu bangsa, HKI merupakan fundamental perekonomian suatu bangsa. ${ }^{3}$ Kemajuan

\footnotetext{
3 Andi Noorsaman Someng dalam presentasinya pada seminar Manfaat dan Strategi dalam Penggunaan Sistem Hak Kekayaan Intelektual oleh Dunia Usaha Termasuk Usaha Kecil dan Menengah pada tanggal 24 Juni 2008 di Jakarta dengan judul: Strategi Nasional dalam Pengembangan Sistem Hak Kekayaan Intelektual menyampaikan bahwa maksud utama dari Kebijakan Nasional Kekayaan Intelektual (KNKI) adalah menjadikan kekayaan intelektual sebagai sebuah mesin baru pertumbuhan (new engine og
} 
ekonomi suatu bangsa dapat dilihat dari seberapa banyak HKI yang dimiliki oleh bangsa tersebut. Semakin banyak HKI yang dimiliki, semakin cepat pertumbuhan ekonomi yang akan dicapai Negara tersebut. ${ }^{4}$ HKI yang dimiliki dapat dijadikan tolok ukur dalam melihat kemajuan dan perkembangan perekonomian suatu bangsa. Sehingga dengan semakin banyaknya HKI yang dimiliki suatu bangsa dapat dijadikan sebagai pemacu perkembangan ekonomi dan meningkatkan daya saing produk yang dihasilkan dari dalam negeri tersebut. Menurut Shahid Alikhan, penerapan sistem HKI merupakan batu loncatan dari sistem ekonomi modern di tingkat nasional dan sekaligus merupakan katalisator pembangunan. Dan HKI merupakan asset untuk pertumbuhan ekonomi yang berbasis ilmu pengetahuan ${ }^{5}$ di era pasar bebas ASEAN mendatang.

Bangka Belitung merupakan sebuah bagian dari gelombang besar persaingan usaha tingkat ASEAN. Peran pelaku usaha

growth) di dalam meningkatkan kesejahteraan ekonomi dan social, dalam Ansori Sinungan, Perlindungan Desain Industri: Tantangan dan Hambatan dalam Praktiknya di Indonesia, Cetakan ke-1, Alimni, Bandung, 2011, Hlm. 146.

4 Ansori Sinungan, Perlindungan Desain Industri: Tantangan dan Hambatan dalam Praktiknya di Indonesia, Cetakan ke-1, Bandung: Alumni, 2011, Hlm. 147

${ }^{5}$ Ibid., Hlm. 148. pada masing-masing daerah perlu diperhatikan untuk mendorong perkembangan perekonomian nasional. Bangka Belitung yang terkenal sebagai penghasil timah perlu adanya perubahan cara pandang dalam mengembangkan perekonomian daerahnya, bukan hanya bertumpu pada hasil timah yang melimpah. Timah merupakan sumber daya alam yang tidak dapat diperbaharui, suatu saat akan habis. Untuk itu perlu adanya strategi peningkatan perekonomian Bangka Belitung yang tidak hanya menyandarkan pada hasil timah semata. Akan tetapi perlu adanya alternative usaha peningkatan perekonomian selain timah yang selama ini masih dijadikan sebagai tumpuan sebagian masyarakat di Bangka Belitung.

Usaha kecil dan menengah yang ada di Bangka Belitung cukup banyak. Jumlah UMKM terbanyak pada tahun 2014 berada di Kabupaten Bangka Barat yang tercatat ada 53.107 UMKM dan yang terendah ada di Pangkalpinang yang tercatat sejumlah 23.826 UMKM. Untuk jumlah keseluruhan UMKM di Bangka Belitung tercatat 289.310 di tahun 2014 lalu. Seperti yang diungkapkan Bangka Pos yang bersumber dari Dinas Koperasi dan UMKM Provinsi Bangka Belitung. ${ }^{6}$

\footnotetext{
${ }^{6}$ Bangka Pos, Minggu, 22 Maret 2015.
} 
Begitu banyaknya UMKM yang berkembang di Bangka Belitung ini menyebabkan perlunya ada pemetaan yang baik mengenai potensi dari pengembangan ekonomi kreatif berbasis ilmu pengetahuan pada desain industri yang ada, sehingga dapat dikembangkan untuk meningkatkan daya saing perekonomian Daerah Bangka Belitung di kancah nasional bahkan internasional. Kreatifitas pelaku usaha sangat dibutuhkan dalam mempertahankan ekonomi Indonesia khususnya dalam bidang desain industri, sehingga desain industri yang dihasilkan pelaku usaha (UMKM) di Indonesia dapat dilindungi dengan baik. Bila telah diketahui potensi desain industri dalam negeri disetiap daerah, maka pemerintah dapat membuat kebijakan perlindungan dan pengembangan ekonomi pada desain industri. Perlindungan desain industri akan sangat mendukung perkembangan perekonomian kreatif Indonesia yang mandiri dan tidak bergantung pada produk luar negeri.

Berdasarkan latar belakang tersebut di atas, maka yang menjadi rumusan masalah dalam penelitian ini adalah bagaimana perlindungan hukum dan potensi desain industri pada ekonomi kreatif yang berbasis ilmu pengetahuan yang dihasilkan oleh UMKM di Kota Pangkalpinang?.

\section{B. PEMBAHASAN}

\section{Ekonomi Kreatif}

Ekonomi kreatif dan industri kreatif adalah satu kesatuan, di masyarakat modern 2 istilah ini sudah tidak asing lagi. Keberadaan ekonomi kreatif mampu menopang kehidupan masyarakat dengan berlandaskan kemandirian, artinya orang tak lagi bergantung pada terbukanya lapangan kerja. Dengan mereka paham akan konsep ekonomi kreatif maka industri kreatif bisa berkembang seperti di luar negeri. Memang di Indonesia sendiri Industri kreatif masih belum maksimal perkembangannya, hal itu dikarenakan masih banyak masyarakat yang pola pikirnya masih berbasiskan kolonial. Artinya sudah terbiasa untuk bekerja pada orang lain, ketergantungan inilah yang membuat orang tidak mampu menciptakan ide-ide baru untuk memandirikan diri sendiri. $^{7}$

Konsep Ekonomi Kreatif merupakan sebuah konsep ekonomi di

\footnotetext{
7 Pengertian Ekonomi Kreatif dan Industri Kreatif Menurut Para Ahli, http://www.fundbisnis.com/pengertian-ekonomikreatif-dan-industri-kreatif-menurut-para-ahli/html, diakses tanggal 29 April 2015, Pukul 10.35 WIB.
} 
era ekonomi baru yang mengintensifkan informasi dan kreativitas dengan mengandalkan ide dan stock of knowledge dari Sumber Daya Manusia (SDM) sebagai faktor produksi utama dalam kegiatan ekonominya. Struktur perekonomian dunia mengalami transformasi dengan cepat seiring dengan pertumbuhan ekonomi, dari yang tadinya berbasis Sumber Daya Alam (SDA) sekarang menjadi berbasis SDM, dari era pertanian ke era industri dan informasi. ${ }^{8}$ Menurut Howkins ekonomi baru telah muncul seputar industri kreatif yang dikendalikan oleh hukum kekayaan intelektual seperti paten, hak cipta, merek, royalti dan desain. Ekonomi kreatif merupakan pengembangan konsep berdasarkan aset kreatif yang berpotensi meningkatkan pertumbuhan ekonomi. (Dos Santos, 2007). ${ }^{9}$

\section{Usaha Mikro, Kecil, dan Menengah \\ Pengertian mengenai usaha} mikro, kecil, dan menengah dapat kita temui dalam Undang-Undang Republik

\footnotetext{
Ekonomi Kreatif, http://arifh.blogdetik.com/ekonomi-kreatif/, diakses tanggal 29 April 2015, Pukul 10.25 WIB.

${ }^{9}$ Ibid.
}

Indonesia Nomor 20 Tahun 2008 tentan Usaha Mikro, Kecil, dan Menengah. Usaha Mikro adalah usaha produktif milik orang perorangan dan/atau badan usaha perorangan yang memenuhi criteria Usaha Mikro sebagaimana diatur dalam Undang-Undang ini. Usaha Kecil adalah usaha ekonomi produktif yang berdiri sendiri, yang dilakukan oleh orang perorangan atau badan usaha yang bukan merupakan anak perusahaan atau bukan cabang perusahaan yang dimiliki, dikuasai, atau menjadi bagian baik langsung maupun tidak langsung dari Usaha Menengah atau Usaha Besar yang memenuhi kriteria Usaha Kecil sebagaimana dimaksud dalam UndangUndang ini. Sedangkan, Usaha Menengah adalah usaha ekonomi produktif yang berdiri sendiri, yang dilakukan oleh orang perorangan atau badan usaha yang bukan merupakan anak perusahaan atau cabang perusahaan yang dimiliki, dikuasai, atau menjadi bagian baik langsung maupun tidak langsung dengan Usaha Kecil atau Usaha Besar dengan jumlah kekayaan bersih atau hasil penjualan tahunan sebagaimana diatur dalam Undang-Undang ini. 
Banyaknya Usaha Mikro, Kecil dan Menengah yang ada di Indonesia dapat memperluas lapangan kerja dan memberikan jasa ekonomis yang luas kepada masyarakat serta berperan dalam proses peningkatan pendapatan masyarakat dan mendorong pertumbuhan ekonomi. Selain itu dapat meningkatkan perekonomian dan APBN Negara. Usaha Mikro, Kecil dan Menengah (UMKM) adalah salah satu tonggak ekonomi Negara yang harus memperoleh kesempatan, dukungan, payung hukum dan kebebasan pengembangan seluas-luasnya sebagai wujud kepedulian pemerintah kepada kelompok usaha ekonomi rakyat tanpa mengabaikan peranan Usaha Besar dan Badan Usaha Milik Negara. ${ }^{10}$

Oleh karena itu pemerintah wajib untuk mengarahkan, membimbing, melindungi serta menumbuhkan iklim usaha. Sehingga UMKM merasa diperhatikan karena sebagian besar penduduk Indonesia hidup dan menggantungkan diri dari sector ini. Meskipun telah memberikan peranan yang besar dalam perekonomian

10 Peran Pemerintah dalam Perekonomian dan Sistem Bisnis, http://akmalfarantfaiz53.blogspot.com/2013/06/arti kel-peran-pemerintah-dalam.html, diakses tanggal 29 April 2015, Pukul 11.05 WIB. nasional, namun sedikit banyak mengalami kendala dan hambatan. Contohnya saja kendala yang bersifat internal yaitu dalam segi Produksi, Pemasaran, SDA, SDM, Teknologi, Modal Usaha. Untuk mengatasi masalah ini pemerintah telah menerbitkan 34 program dan kebijakan ekonomi lanjutan untuk Sektor UMKM Pada 2008-2009 diantaranya percepatan pengembangan sector riil dan pemberdayaan UMKM. ${ }^{11}$ Selain itu kendala yang juga kadang terabaikan adalah pada perlindungan dalam hak kekayaan intelektualnya yang pada saat ini menjadi permasalahan yang serius bagi para pelaku usaha di Indonesia.

\section{Perlindungan Hukum}

Beberapa pengertian mengenai perlindungan hukum menurut para ahli sebagai berikut. $^{12}$

1) Menurut Satjipto Raharjo mendefinisikan Perlindungan Hukum adalah memberikan pengayoman kepada hak asasi manusia yang dirugikan orang lain dan perlindungan tersebut diberikan kepada masyarakat agar mereka dapat menikmati

\footnotetext{
11 Ibid.

12 http://tesishukum.com/pengertianperlindungan-hukum-menurut-para-ahli/ diunduh pada tanggal 1 Agustus 2016, pukul 21.00 wib.
} 
semua hak-hak yang diberikan oleh hukum.

2) Menurut Philipus M. Hadjon berpendapat bahwa Perlindungan Hukum adalah perlindungan akan harkat dan martabat, serta pengakuan terhadap hak-hak asasi manusia yang dimiliki oleh subyek hukum berdasarkan ketentuan hukum dari kesewenangan.

3) Menurut CST Kansil Perlindungan Hukum adalah berbagai upaya hukum yang harus diberikan oleh aparat penegak hukum untuk memberikan rasa aman, baik secara pikiran maupun fisik dari gangguan dan berbagai ancaman dari pihak manapun.

4) Menurut Philipus M. Hadjon Perlindungan Hukum adalah Sebagai kumpulan peraturan atau kaidah yang akan dapat melindungi suatu hal dari hal lainnya. Berkaitan dengan konsumen, berarti hukum memberikan perlindungan terhadap hak-hak pelanggan dari sesuatu yang mengakibatkan tidak terpenuhinya hak-hak tersebut.

Berbicara mengenai perlindungan hukum, bila dikaitkan dengn kekayaan intelektual maka akan terdapat konsep perlindungan hukum yang berbeda dan lebih khusus. Nilai-nilai yang terkandung dalam substansi hukum HKI mengandung nilai yang individualistik, monopolistik, materialistik dan kapitaistik.
Individualistik karena sistem hukum kekayaan intelektual mengakui dan melindungi hasil karya intelektual (work dan invention) sebagai kekayaan yang bisa menjadi hak milik individu; monopolistik karena hukum memberikan hak eksklusif terhadap pemegang HKI dalam jangka waktu tertentu mempunyai hak memanfaatkan karya intelektualnya secara leluasa dan hak untuk mencegah pihak lain memakai ataupun menggunakan hasil karya intelektualnya (untuk hak cipta masa perlindungan sangat panjang); materialistik karena pemilik HKI dapat mengeksploitasi sebesar-besarnya manfaat ekonomi (keuntungan materi) dari kepemilikan HKI-nya tanpa gangguan dari pihak-pihak lain dan kapitalistik karena sistem hukum HKI menciptakan suatu kondisi lebih banyak melindungi kepentingan pemilik modal sebagai pemegang HKI daripada pencipta ataupun penemu. ${ }^{13}$ Sehingga akan ditemui konsep perlindungan hukum yang berbeda pada HKI.

Penegakan hukum sebagai salah satu konsekuensi HKI sebagai obyek

13 Kholis Roisah, Konsep Hukum Hak Kekayaan Intelektual, Setara Press, Jatim, 2015, Hlm. 93. 
kekayaan (property) yang memberikan kewenangan pemilik untuk menentukan siapa yang boleh memperoleh manfaat dari kreasi intelektualnya. Pada dasarnya ada asumsi hak (right), kewajiban (obligation) dan keistimewaan (prevelege) dari HKI bersifat absolute dan universal. ${ }^{14}$

HKI menjadi faktor strategis penentu daya saing sekaligus symbolsimbol prestasi era globalisasi. HKI menjadi andalan dalam memenangkan rivalitas industri dan perdagangan. ${ }^{15}$ Perlu adanya perhatian yang khusus terhadap perlindungan hukum HKI yang selama ini masih belum menjadi prioritas di Indonesia. Mengingat bahwa fenomena perang dagang, menjadikan pebangunan sistem HKI nasional yang modern dan efektif merupakan kebutuhan nyata.

\section{Hak Kekayaan Intelektual}

Hukum adalah tata aturan (order) sebagai suatu sistem aturan-aturan

\footnotetext{
${ }^{14}$ Rahmi Jened Parinduri Nasution, Interface Hukum Kekayaan Intelektual dan Hukum Persaingan Usaha (Penyalahgunaan HKI), Rajawali Press, Jakarta, 2013, Hlm. 326.

15 Hendry Soelistyo, Hak Kekayaan Intelektual: Konsep, Opini dan Aktualisasi, Penaku, Jakarta, 2014, Hlm. 5.
}

(rules) tentang perilaku manusia. ${ }^{16}$ Hukum akan dijadikan acuan dalam mengendalikan perilaku masyarakat yang menyimpang. Hukum juga akan memberikan batasan-batasan yang dapat dilakukan seseorang dalam perbuatannya dalam berbagai bidang.

Perkembangan perekonomian yang begitu pesat, banyak menyebabkan penyimpanganpenyimpangan yang dilakukan dalam kegiatan ekonomi. Butuh adanya suatu aturan hokum agar kegiatan ekonomi dapat berjalan dengan baik sesuai dengan yang diinginkan Negara dan masyarakat. Kegiatan ekonomi yang sudah lintas Negara ini menimbulkan persaingan yang ketat antara pelaku usaha sehingga pelaku usaha membutuhkan suatu inovasi agar kegiatan usahanya dapat berjalan dengan baik dan bisa bertahan dikancah persaingan nasional bahkan internasional. Kreatifitas dalam kegiatan ekonomi atau usaha pada saat ini telah dikendalikan oleh hukum kekayaan intelektual.

Kekayaan intelektual (KI) adalah hasil olah pikir otak manusia yang

16 Jimly Asshiddiqie dan M. Ali Saa'at, Teori Hans Kelsen Tentang Hukum, Cetakan Ketiga, Konstitusi Press, Jakarta, 2012 Hlm. 13. 
berwujud dalam bidang teknologi, ilmu pengetahuan, seni, dan sastra. ${ }^{17}$ Dengan adanya pengembangan oleh pikir manusia yang diwujudkan dalam bentuk yang nyata akan memberikan dampak yang nyata dalam perkembangan sebuah budaya dan peningkatan perubahan social masyarakat. Hasil dari oleh pikir manusia tersebut yang telah berbentuk nyata memberikan pengaruh pada berkembangnya peradaban manusi menjadi lebih maju.।

Kekayaan Intelektual berkaitan dengan proses penciptaan sesuatu yang baru,dengan demikian maka subjek kekayaan intelektual terkandung masalah hak dan kewajiban bagi inividu yang mampu dan dapat menciptakan serta menghasilkan karya intelektual. $^{18}$ Sehingga hak dan kewajiban yang terkandung dalam subjek kekayaan intelektual harus dapat dilindungi dengan aturan hukum yang ada.

Saat ini perlindungan terhadap hak dari kekayaan intelektual yang telah dihasilkan subjek hukum telah

17 Sudarmanto, KI \& HKI Serta Implementasinya bagi Indonesia, Elex Media Komputindo, Jakarta, 2012, Hlm. 2-3.

${ }^{18}$ Ibid., Hlm. 3. dituangkan dalam berbagai perundangundangan diantaranya adalah perundang-undangan yang terkait dengan hak cipta, hak merek, hak paten, desain industry, desain tata letak sirkuit terpadu, rahasia dagang, dan perlindungan varietas tanaman.

HKI (Intellectual Property Right) adalah kependekan dari hak kekayaan intelektual. HKI merupakan hak untuk menikmati hasil kreativitas intelektual manusia secara ekonomis. ${ }^{19}$ Hak untuk menikmati hasil kreativitas intelektual manusi secara ekonomis dapat disebut hak ekonomi. Hak ekonomi adalah hak yang dimiliki oleh seseorang inventor dan pendesain untuk mendapatkan keuntungan atas invensi dan karya desain industrinya. Hak ekonomi tersebut berkembang dengan pemanfaatan hak secara komersial. ${ }^{20}$

Seperti yang dituangkan dalam Pasal 1 Undang-Undang Republik Indonesia Nomor 14 Tahun 2001 tentang Paten dijelaskan bahwa invensi adalah ide inventor yang dituangkan ke dalam suatu kegiatan pemecahan masalah yang spesifik dibidang teknologi dapat berupa produk atau

\footnotetext{
${ }^{19}$ Sudaryat, dkk., Hak Kekayaan Intelektual, Cetakan I, Oase Media, Bandung, 2010, Hlm. 15.

${ }^{20}$ Sudarmanto, Op. Cit., Hlm. 1.
} 
proses, atau penyempurnaan dan pengembangan produk atau proses. ${ }^{21}$ Seseorang yang menghasilkan kekayaan intektual dalam bentuk nyata sebelumnya disebut inventor (dalam hal paten) dan pendesain (dalam hal desain). Inventor adalah seorang yang secara sendiri atau beberapa orang yang secara bersama-sama melaksanakan ide yang dituangkan ke dalam kegiatan yang menghasilkan invensi. ${ }^{22}$ Sedangkan pendesain dalam Pasal 1 Undang-Undang Republik Indonesia Nomor 31 Tahun 2000 tentang Desain Industri dijelaskan bahwa pendesain adalah seorang atau beberapa orang yang menghasilkan desain industri. ${ }^{23}$

Berbicara mengenai hak ekonomi, pemilik dari hak kekayaan intelektual berhak mendapatkan keuntungan atas karyanya tersebut. Hak tersebut juga dapat dialihkan dengan menggunakan perjanjian lisensi. Lisensi diartikan sebagai salah satu bentuk pemberian izin untuk memanfaatkan HKI milik pihak lain melalui pembayaran royalti. ${ }^{24}$

21 Undang-Undang Republik Indonesia Nomor 14 Tahun 2001 tentang Paten.

${ }^{22}$ Ibid., Hlm. 159.

${ }^{23}$ Ibid., Hlm. 86.

${ }^{24}$ Sudaryat, Op. Cit., Hlm. 17.
HKI perlu adanya perlindungan. Kenapa perlu dilindungi? Merujuk pada salah satu teori perlindungan HKI yang dikemukakan oleh Robert C. Sherwood sebagaimana dikutip oleh Ranti Fauza Mayana dan dikutip kembali oleh Sudaryat, Sudjana, dan Rika Ratna Permata, dalam bukunya yang berjudul Hak Kekayaan Intelektual, yaitu Economic Growth Stimulus Theory. Dalam teori tersebut menjelaskan bahwa perlindungan atas HKI merupakan alat pembangunan ekonomi. Pembangunan ekonomi adalah keseluruhan tujuan dibangunnya sistem perlindungan atau HKI yang efektif. $^{25}$

HKI telah menjadi bagian terpenting suatu Negara untuk menjaga keunggulan industry dan perdagangannya. Diakui bahwa pertumbuhan ekonomi suatu Negara sangat bergantung kepada sektor perdagangannya, yang pada akhirnya ditentukan pula oleh keunggulan komparatif yang dimilikinya. Keunggulan komparatif sangat bergantung kepada kemampuan teknologinya, salah satu unsurnya adalah pada bidang cakupan kekayaan

\footnotetext{
${ }^{25}$ Ibid., Hlm. 20.
} 
intelektual. ${ }^{26}$ Seperti yang diungkapkan dalam Kompas tanggal 30 Maret 2000 yang berjudul Aset Karya Intelektual Banyak Dicuri Pihak Asing sebagaimana dikutip oleh Adrian Sutedi bahwa Indonesia dikenal memiliki keragaman hayati yang tinggi, keberagaman hayati budaya dan karya tradisional. Tanpa disadari bahwa banyak asset dan kekayaan intelektual local itu telah banyak terdaftar di luar negeri sebagai milik asing. Kurangnya kesadaran akan pentingnya asset karya intelektual ini telah mengakibatkan kerugian besar bagi Indonesia. ${ }^{27} \mathrm{Hal}$ tersebut menunjukan bahwa betapa perlunya perlindungan hak kekayaan intelektual yang banyak dihasilkan oleh masyarakat. Sehingga dapat meningkatkan perkembangan perekonomian baik skala lokal maupun nasional.

\section{Desain Industri}

Pengertian desain industri dapat dilihat dalam Pasal 1 Undang-Undang Nomor 1 Tahun 2000 tentang Desain Industri. Desain Industri adalah suatu

${ }^{26}$ Muhamad Djumhana dan Djubaedillah, Hak Milik Intelektual Sejarah, Teori dan Prakteknya di Indonesia, Citra Aditya Bakti, Bandung, 2003, Hlm. 10.

27 Adrian Sutedi, Hak Atas Kekayaan Intelektual,Sinar Grafika, Jakarta, 2009, Hlm. 6. kreasi tentang bentuk, konfigurasi, atau komposisi garis atau warna, atau garis dan warna, atau gabungan daripadanya yang berbentuk tiga dimensi atau dua dimensi yang memberikan kesan estetis dan dapat diwujudkan dalam pola tiga dimensi atau dua dimensi serta dapat dipakai untuk menghasilkan suatu produk, barang, komoditas industry, atau kerajinan tangan. Cakupan bidang desain meliputi cara penanganan berbagai bidang, seperti seni, kerajinan, pelajaran lingkungan, teknologi, bahkan lebih luas lagi, meliputi ilmu kemasyarakatan dan peningkatan taraf kehidupan. $^{28}$ Boleh dikatakan bahwa desain industry merupakan hak kekayaan intelektual manusia yang bernilai seni pakai dan dihasilkan oleh industry. ${ }^{29}$

Di awal telah dikemukakan bahwa hak kekayaan intelektual perlu adanya perlindungan dikarenakan sangat berpengaruh terhadap bidang ekonomi suatu bangsa. Perlindungan bagi pemegang hak desai industry mencakup hak khusus untuk melaksanakan desain industry yang dimilikinya dan melarang orang lain

\footnotetext{
${ }^{28}$ Sudaryat, dkk., Op. Cit., Hlm. 114.

${ }^{29}$ Ibid., Hlm. 116.
} 
yang tanpa persetujuannya membuat, memakai, menjual atau mengimpor produk yang diberikan hak desain industry itu, kecuali apabila pemakai lisensi yang bersangkutan adalah untuk kepentingan penelitian dan pendidikan sepanjang tidak merugikan secara wajar hak dari pemegang desain industry. $^{30}$ Hak khusus tersebut memungkinkan penerima hak khusus tersebut dapat melakukan produksi atau memberikan lisensi kepada orang lain dan sebagai imbalannya, ia akan mendapatkan royalty dari penggunaan atau produksi dari desain industry yang ia miliki. Seperti yang diungkapkan oleh Robert C. Sherwood dalam teorinya yaitu reward theory. Dalam teori tersebut diungkapkan bahwa pengakuan terhadap karya intelektual yang telah dihasilkan oleh penemu/pencipta/pendesain sehingga ia harus diberi penghargaan sebagai imbangan atas upaya kreatifnya dalam menemukan/menciptakan karya intelektualnya. ${ }^{31}$ Pendesain/pencipta atau sebutan lain bila diberikan penghargaan akan hasil karyanya akan semakin bersemangat dalam menghasilkan karya-karya baru yang bermanfaat bagi masyarakat. Bila semakin banyak orang yang kreatif dalam menciptakan atau menghasilkan suatu karya intelektualnya maka akan semakin meningkat pula perekonomian mereka. Pemegang hak desain industry juga memiliki hak eksklusif untuk melaksanakan hak desain industry yang dimilikinya dan untuk melarang orang lain yang tanpa persetujuannya membuat, memakai, menjual, mngimpor, mengekspor, dan/atau mengedar barang yang diberi hak desain industry. ${ }^{32}$

Berbicara mengenai perlindungan desain industry dapat dikaitkan dengan peningkatan pertumbuhan ekonomi. Untuk mengetahui seberapa jauh kemajuan ekonomi yang sudah yang sudah dicapai oleh suatu bangsa dapat dilihat dari seberapa banyak HKI yang dimiliki oleh bangsa tersebut. Semakin banyak HKI yang dimiliki, maka akan semakin cepat pula pertumbuhan ekonomi yang akan dicapai Negara
30 Badan Pengkajian dan Penerapan Teknologi, Hak Kekayaan Intelektual Suatu Panduan di Lingkungan BPPT, Unit Pengelola HKI-BPPT, Jakarta, 2011, Hlm. 7-8.

${ }^{31}$ Sudaryat, dkk., Op. Cit., Hlm. 19.
${ }^{32}$ Tim Lindsey, dkk. (Editor), Hak Kekayaan Intelektual Suatu Pengantar, Alumni, Bandung, 2011, Hlm. 222. 
Indonesia. ${ }^{33}$ Bila kita kaitkan dengan lingkup suatu daerah atau lingkup lokal, semakin banyak HKI yang dimiliki suatu daerah, dari hasil karya intelektual masyarakatnya, maka dapat meningkatkan pertumbuhan ekonomi suatu daerah.

Keberadaan potensi kekayaan budaya dan etnis bangsa Indonesia yang beranekaragam tersebut, jika dikaitkan dengan tujuan perlindungan desain industry, kemajuan ekonomi yang berbasis industry kreatif. ${ }^{34}$

Perlindungan hukum merupakan suatu bagian yang harus diperhatikan dalam dunia usaha. Pasar yang ada saat ini berupa pasar bebas. Terdapat banyak penjual dan pembeli untuk masing-masing produk barang atau jasa. Jumlah produk yang dibeli oleh pembeli atau dijual oleh penjual sangat kecil bila dibandingkan dengan total jumlah produk yang diperdagangkan, jumlah ini sedemikian besar sehingga harga pasar untuk masing-masing produk tersebut tidak terpengaruh oleh penjual atau pembeli yang terjadi. Jenis produk homogen, sehingga tidak ada

33 Ansori Sinungan, Perlindungan Desain Industri: Tantangan dan Hambatan dalam Praktiknya di Indonesia, Alumni, Bandung, 2011, Hlm. 146-147.

${ }^{34}$ Ibid., Hlm. 268. alasan bagi konsumen untuk memilih penjual tertentu dan juga sebaliknya. Begitulah pasar bebas yang menuntut pelaku usaha dan konsumen dengan cerdas untuk memperdagangkan dan memilih produk.

Pasar bebas menuntut persaingan usaha yang ketat. Terdapat banyak pelaku usaha yang menawarkan banyak jenis produk sejenis. Sehingga pembeli akan termanjakan oleh banyaknya pilihan produk. Persaingan usaha yang begitu ketat membuat pelaku usaha kadang melakukan hal-hal yang dapat merugikan konsumen maupun pesaing dalam bisnisnya. Sehingga perlindungan hukum dibutuhkan untuk melindungi pelaku usaha atau konsumen.

Berbicara mengenai perlindungan hukum, pada penelitian ini akan mengkaji perlindungan hukum bagi desain industri yang memenuhi syarat dapat dilindungi oleh pemerintah melalui Undang-Undang Desain Industri dengan inisiatif untuk melindungi hadir dari pendesain yang membuat desain tersebut. Desain industri yang dapat dilindungi harus memenuhi kriteria yang ada dalam Undang-Undang Desain Industri. 
Perlu diingat bahwa dalam melindungi desain produk yang dihasilkan oleh para pelaku usaha yang dalam hal ini adalah UMKM yang harus berperan keaktifan adalah pelaku usaha itu sendiri. Sehingga pelaku usaha yang harus mempunyai inisiatif untuk mendaftarkan hasil desainnya ke Dirjen HKI untuk mendapatkan sertifikat desain insustri yang dihasilkannya. Bila pelaku usaha tidak mendaftarkan desainnya sampai mendapatkan sertifikat desain industry, maka negara tidak akan dapat memberikan perlindungan atas desainnya tersebut. Walupun dalam melindungi desain yang dihasilkan oleh pelaku usaha dapat dilakukan bersamasama antara pelaku usaha dan penegak hukum yang dalam hal ini mewakili negara, serta stakeholder yang peduli akan desain industry.

Desain Industri adalah suatu kreasi tentang bentuk, konfigurasi, atau komposisi garis atau warna, atau garis dan warna, atau gabungan daripadanya yang berbentuk tiga dimensi atau dua dimensi yang memberikan kesan estetis dan dapat diwujudkan dalam pola tiga dimensi atau dua dimensi serta dapat dipakai untuk menghasilkan suatu produk, barang, komoditas industri, atau kerajinan tangan. Sedangkan pendesain adalah seorang atau beberapa orang yang menghasilkan Desain Industri.

Desain industry yang dapat dilindungi dengan Undang-Undang Desain Industri adalah untuk desain industry yang baru. Desain Industri dianggap baru apabila pada Tanggal Penerimaan, desain Industri tersebut tidak sama dengan pengungkapan yang telah ada sebelumnya. Desain industry yang diteliti dalam penelitian ini adalah desain industry yang dibuat oleh pendesain sendiri, tidak meniru atau membuat desain yang umumnya telah ada.

Desain yang benar-benar mempunyai keunikan dan nilai seni memiliki potensi untuk dikembangkan sebagai salah satu sarana untuk membantu meningkatkan perekonomian masyarakat dan dapat menunjang pariwisata yang ada di Kota Pangkalpinang khususnya. Desain industry diharapkan banyak dihasilkan oleh Usaha Mikro Kecil dan Menengah (UMKM) yang ada di Kota Pangkalpinang. 
Penelitian ini mengkaji mengenai perlindungan hukum desain industri pada UMKM dan potensi desain industrinya di Kota Pangkalpinang. Hasilnya akan diuraikan berikut ini.

\section{a. Perlindungan Hukum Desain Industri pada UMKM di Kota Pangkalpinang}

Penelitian mengenai perlindungan hukum terhadap desain industri dilakukan di Kota Pangkalpinang. Subyek penelitian pada penelitian ini adalah usaha mikro kecil dan menengah (UMKM) yang menghasilkan desain industry yang memenuhi criteria dalam undangundang desain industri yang dapat dilindungi secara hukum.

Usaha yang termasuk dalam UMKM adalah yang memenuhi criteria yang ada dalam undang-undang UMKM. Usaha Mikro adalah usaha produktif milik orang perorangan dan/atau badan usaha perorangan. Usaha mikro memiliki kekayaan bersih paling banyak Rp50.000.000,00 (lima puluh juta rupiah) tidak termasuk tanah dan bangunan tempat usaha dan memiliki hasil penjualan tahunan paling banyak Rp300.000.000,00 (tiga ratus juta rupiah). Usaha Kecil adalah usaha ekonomi produktif yang berdiri sendiri, yang dilakukan oleh orang perorangan atau badan usaha yang bukan merupakan anak perusahaan atau bukan cabang perusahaan yang dimiliki, dikuasai, atau menjadi bagian baik langsung maupun tidak langsung dari Usaha Menengah atau Usaha Besar. Usaha kecil memiliki kekayaan bersih lebih dari Rp50.000.000,00 (lima puluh juta rupiah) sampai dengan paling banyak Rp500.000.000,00 (lima ratus juta rupiah) tidak termasuk tanah dan bangunan tempat usaha atau memiliki hasil penjualan tahunan lebih dari Rp300.000.000,00 (tiga ratus juta rupiah) sampai dengan paling banyak Rp2.500.000.000,00 (dua milyar lima ratus juta rupiah). Sedangkan Usaha Menengah adalah usaha ekonomi produktif yang berdiri sendiri, yang dilakukan oleh orang perorangan atau badan usaha yang bukan merupakan anak perusahaan atau cabang perusahaan yang dimiliki, dikuasai, atau menjadi bagian baik langsung maupun tidak langsung dengan Usaha Kecil atau Usaha Besar dengan jumlah kekayaan bersih atau hasil penjualan tahunan. UMKM yang menghasilkan desain industri yang baru dan kreatif 
yang menjadi sasaran dalam penelitian ini.

Desain Industri adalah suatu kreasi tentang bentuk, konfigurasi, atau komposisi garis atau warna, atau garis dan warna, atau gabungan daripadanya yang berbentuk tiga dimensi atau dua dimensi yang memberikan kesan estetis dan dapat diwujudkan dalam pola tiga dimensi atau dua dimensi serta dapat dipakai untuk menghasilkan suatu produk, barang, komoditas industri, atau kerajinan tangan. Desain industri yang dijadikan sampel atau sasaran dalam penelitian ini dibatasi ruang lingkupnya hanya pada desain industri yang diciptakan sendiri oleh pendesain, unik dan memenuhi kriteria desain yang dapat dilindungi oleh undangundang desain industri. Kriteria desain industri yang dapat dberikan hak perlindungan dalam penelitian ini adalah desain industri yang baru. Untuk dapat memberikan perlindungan melalui undang-undang desain industri bahwa desain industri dianggap baru apabila pada Tanggal Penerimaan, Desain Industri tersebut tidak sama dengan pengungkapan yang telah ada sebelumnya. Jadi desain industri dianggap benar-benar baru apabila tidak sama dengan desain yang telah ada sebelumnya. Perlindungan berupa hak desain industri tidak akan diberikan pada desain yang bertentangan dengan peraturan perundang-undangan yang berlaku, ketertiban umum, agama, atau kesusilaan.

Dari hasil penelitian yang dilakukan di Kota Pangkalpinang baru ditemukan beberapa desain yang dihasilkan oleh UMKM yang kemungkinan dapat memenuhi kriteria desain yang baru atau didesain sendiri. Akan tetapi desain tersebut belum bisa dikatakan baru dan dapat dilindungi menurut undang-undang desain industri apabila belum memenuhi unsur pada Pasal 2 dan 3 Undang-Undang Desain Industri. Desain yang dikatakan dapat dilindungi hukum pada pasal tersebut dapat akan dijelaskan lebih lanjut sebagai berikut.

a) Desain telah diajukan permohonan untuk mendapatkan hak desain industri ke Direktorat Jenderal HKI.

Dari hasil penelitian yang dilakukan terhadap desain industri baru yang dihasilkan oleh UMKM di Kota Pangkalpinang sampai saat ini masih sedikit desain industri yang dianggap baru telah diajukan 
ke Dirjen HKI melalui Kanwil Hukum dan HAM untuk mendapatkan hak desain industri.

\section{b) Desain Industri dianggap baru} Desain industri dianggap baru apabila pada Tanggal Penerimaan, Desain Industri tersebut tidak sama dengan pengungkapan yang telah ada sebelumnya. Telah dijelaskan dalam undang-undang desain industri bahwa yang dimaksud pengungkapan yang telah ada sebelumnya adalah pengungkapan Desain Industri yang sebelum tanggal penerimaan, tanggal prioritas apabila Permohonan diajukan dengan Hak Prioritas, atau telah diumumkan atau digunakan di Indonesia atau di luar Indonesia. Dari hasil penelitian bahwa hanya sebagian saja dari desain yang dapat memenuhi kriteria kebaruannya

c) Mendapatkan sertifikat desain industri

Penelitian yang dilakukan di Kota Pangkalpinang terhadap desain industri, belum ditemukan desain yang mendapatkan sertifikat hak desain industri. Desain industri yang inovatif yang dihasilkan oleh
UMKM yang ada di Kota Pangkalpinang masih belum banyak. Produk yang dihasilkan masih sebagian mengambil dari luar kota dan tidak mendesain sendiri. Seperti misalnya produk furniture, fashion, dan lain-lain masih banyak mengambil dari luar kota atau pulau. Sehingga banyak desain produk didominasi buatan luar kota. Akan tetapi terdapat beberapa jenis produk yang desainnya hasil dari kreativitas masyarakat, misalnya batik tulis, bentuk sablon pada baju/kaos, souvenir, dan lain sebagainya. Akan tetapi desain produk tersebut masih terbatas.

Hasil observasi dan wawancara langsung kepada UMKM terdapat beberapa faktor yang menghambat perlindungan terhadap desain industri yang dianggap baru. Faktor yang menjadi penyebab tidak terlindunginya desain industri yang ada di Kota Pangkalpinang adalah sebagai berikut.

1) Kesadaran hukum masyarakat yang rendah.

2) Ketidaktahuan masyarakat pada peraturan perundang-undangan tentang desain industri. 
3) Kurangnya sosialisasi pentingnya perlindungan terhadap desain industri bagi masyarakat (pelaku usaha).

4) Adanya pemahaman masyarakat yang salah dalam memahami perlindungan terhadap desain yang dihasilkannya.

5) Peran pemerintah belum optimal dalam memberikan pemahaman mengenai perlindungan desain industri dan manfaatnya.

6) Kemauan masyarakat untuk melindungi desain yang dihasilkannya kurang.

7) Masyarakat (pelaku usaha/UMKM) masih menganggap belum penting atau perlu untuk melindungi desain yang dihasilkannya.

8) Keengganan mendaftarkan desainnya dikarenakan waktu yang dibutuhkan untuk pendaftaran cukup lama.

9) Biaya mahal

10) Pelaku usaha tidak mau memonopoli usahanya

11) Produk dipasarkan masih sebatas pada masyarakat lokal.

12) Keterbatasan bahan baku.
13) Pelaku usaha merasa senang produknya ditiru oleh pengrajin lain.

Pada tahun 2016 di Kota Pangkalpinang terdapat 2795 usaha mikro, 1095 usaha kecil dan 90 usaha menengah (sumber: Dinas Perindustrian, Perdangangan, Koperasi dan UMKM Kota Pangkalpinang). Desain pada ekonomi kreatif yang berbasis ilmu pengetahuan yang dihasilkan oleh UMKM di Kota Pangkalpinang belum banyak. Desain yang dihasilkan dari kreatifitas pelaku usaha pada UMKM masih belum dilindungi dengan baik. Hal tersebut dikarenakan desain yang mereka hasilkan masih belum jelas unsur kebaruannya dan belum didaftarkan untuk memperoleh sertifikat desain industri. Secara garis besar terdapat beberapa alasan yang menyebabkan pelaku usaha enggan untuk melindungi hasil desain industri pada produknya diantaranya yaitu pelaku usaha tidak mau memonopoli usahanya, waktu pendaftaran yang relatif masih lama menurut pelaku usaha, kesadaran hukum pelaku usaha yang rendah, ketidaktahuan masyarakat akan undang-undang desain industri dan 
adanya pemahaman masyarakat yang salah dalam memahami perlindungan terhadap desain yang dihasilkannya. Sehingga perlu adanya pembenahan dalam melakukan sosialisasi yang efektif dan berkelanjutan serta pembianaan agar masyarakat dapat terdorong untuk lebih sadar dalam mengamankan asset yang sangat berharga yaitu desain industri hasil ciptaannya.

\section{b. Potensi Desain Industri pada UMKM di Kota Pangkalpinang}

Berbicara mengenai potensi desain industri pada UMKM, yang perlu diperhatikan adalah pada keunggulan komparatif dan keunggulan kompetitif. Keunggulan kompetitif timbul jika perusahaan mampu menjual barang yang sama yang dimiliki oleh pesaing tatapi dengan harga yang lebih rendah, atau memberikan manfaat yang melebihi pesaingnya. Oleh karena itu, keunggulan kompetitif akan dapat menjadikan perusahaan menciptakan produk-produk yang memiliki nilai lebih sehingga tidak saja akan memberikan keuntungan bagi pelanggan tetapi juga bagi perusahaan itu sendiri. ${ }^{35}$

Data desain industri yang dihasilkan atau diciptakan oleh pelaku usaha pada UMKM di wilayah kota Pangkalpinang meliputi 7 (tujuh) kecamatan yaitu Kecamatan Bukit Intan, Kecamatan Gabek, Kecamatan Gerunggang, Kecamatan Girimaya, Kecamatan Pangkalbalam, Kecamatan Rangkui dan Kecamatan Tamansari. Sampel informan yang diambil dalam penelitian ini adalah informan yang mempunyai desain yang diciptakannya sendiri dengan menggunakan metode purposive sample. Purposive sample merupakan populasi yang akan dijadikan sampel telah memenuhi kriteria tertentu kemudian dipilih berdasarkan pertimbangan yang sesuai dengan tujuan penelitian. Purposive sample disebut sempel tujuan, artinya memilih sampel berdasarkan penilaian tertentu karena unsur-unsur, atau unitunit yang dipilih dianggap mewakili populasi. $^{36}$ Kriteria informan yang dijadikan sampel dalam penelitian ini adalah pelaku usaha pada UMKM yang

\footnotetext{
35 Ansori Sinungan, Op. Cit., Hlm. 279.

${ }^{36}$ Bahder Johan Nasution, Metode Penelitian Ilmu Hukum, CV. Mandar Maju, Bandung, 2008, Hlm. 159-160.
} 


\begin{abstract}
telah mempunyai desain yang diciptakannya sendiri dan tidak mengambil dari desain yang dimiliki pelaku usaha lain dan mempunyai keunikan tersendiri dalam jenis produknya. Sampel ini diambil dari hasil survey dan observasi di 7 (Tujuh) kecamatan yang ada di Kota Pangkalpinang.

Untuk menguraikan mengenai potensi desain industri yang dianggap baru akan disajikan terlebih dahulu data desain yang didapat dari hasil observasi lapangan di wilayah Kota Pangkalpinang sebagai berikut.
\end{abstract}




\begin{tabular}{|c|c|c|c|c|}
\hline No. & Jenis Desain & Tempat & Sertifikat & Keterangan \\
\hline 1. & $\begin{array}{l}\text { Desain dari kaca } \\
\text { (pintu, lemari, dll) }\end{array}$ & Opas Indah & $\begin{array}{l}\text { Tidak bersertifikat } \\
\text { hak desain industri }\end{array}$ & $\begin{array}{l}\text { Belum jelas } \\
\text { kebaruan desainnya }\end{array}$ \\
\hline 2. & $\begin{array}{l}\text { Interior Rumah dari } \\
\text { bahan semen dan kayu } \\
\text { (Pot, meja, kursi, dll) }\end{array}$ & Kacang Pedang & $\begin{array}{l}\text { Tidak bersertifikat } \\
\text { hak desain industri }\end{array}$ & $\begin{array}{l}\text { Belum jelas } \\
\text { kebaruan desainnya }\end{array}$ \\
\hline 3. & $\begin{array}{l}\text { Interior Rumah dari } \\
\text { bahan semen dan } \\
\text { tanah liat (Pot, meja, } \\
\text { kursi, dll) }\end{array}$ & Air Itam & $\begin{array}{l}\text { Tidak bersertifikat } \\
\text { hak desain industri }\end{array}$ & $\begin{array}{l}\text { Belum jelas } \\
\text { kebaruan desainnya }\end{array}$ \\
\hline 4. & $\begin{array}{l}\text { Accesoris (bros, } \\
\text { bantal, dll) }\end{array}$ & Gabek Dua & $\begin{array}{l}\text { Tidak bersertifikat } \\
\text { hak desain industri }\end{array}$ & $\begin{array}{l}\text { Belum jelas } \\
\text { kebaruan desainnya }\end{array}$ \\
\hline 5. & Tas dari bahan talikur & Gabek Dua & $\begin{array}{l}\text { Tidak bersertifikat } \\
\text { hak desain industri }\end{array}$ & $\begin{array}{l}\text { Belum jelas } \\
\text { kebaruan desainnya }\end{array}$ \\
\hline 6. & Desain interior & Rejosari & $\begin{array}{l}\text { Tidak bersertifikat } \\
\text { hak desain industri }\end{array}$ & $\begin{array}{l}\text { Belum jelas } \\
\text { kebaruan desainnya }\end{array}$ \\
\hline 7. & $\begin{array}{l}\text { Accesoris (Gantungan } \\
\text { kunci, bros, dll) }\end{array}$ & Masjid Jamik & $\begin{array}{l}\text { Tidak bersertifikat } \\
\text { hak desain industri }\end{array}$ & $\begin{array}{l}\text { Belum jelas } \\
\text { kebaruan desainnya }\end{array}$ \\
\hline 8. & $\begin{array}{l}\text { Kopiyah resam, bros } \\
\text { dari cangkang keong }\end{array}$ & $\begin{array}{l}\text { Kampung } \\
\text { Asem }\end{array}$ & $\begin{array}{l}\text { Tidak bersertifikat } \\
\text { hak desain industri }\end{array}$ & $\begin{array}{l}\text { Belum jelas } \\
\text { kebaruan desainnya }\end{array}$ \\
\hline 9. & $\begin{array}{l}\text { Lemari kaca dan } \\
\text { aluminium }\end{array}$ & $\begin{array}{l}\text { Kampung } \\
\text { Bintang }\end{array}$ & $\begin{array}{l}\text { Tidak bersertifikat } \\
\text { hak desain industri }\end{array}$ & $\begin{array}{l}\text { Belum jelas } \\
\text { kebaruan desainnya }\end{array}$ \\
\hline 10. & $\begin{array}{l}\text { Etalase dan lemari } \\
\text { bahan kaca }\end{array}$ & Kacang Pedang & $\begin{array}{l}\text { Tidak bersertifikat } \\
\text { hak desain industri }\end{array}$ & $\begin{array}{l}\text { Belum jelas } \\
\text { kebaruan desainnya }\end{array}$ \\
\hline 11. & Batik tulis & Selindung & $\begin{array}{l}\text { Proses pendaftaran } \\
\text { untuk memperoleh } \\
\text { hak desain industri }\end{array}$ & $\begin{array}{l}\text { Belum jelas } \\
\text { kebaruan desainnya }\end{array}$ \\
\hline 12. & Kerajinan dari pewter & Pangkalpinang & $\begin{array}{l}\text { Tidak bersertifikat } \\
\text { hak desain industri }\end{array}$ & $\begin{array}{l}\text { Belum jelas } \\
\text { kebaruan desainnya }\end{array}$ \\
\hline
\end{tabular}


Desain-desain industri yang dihasilkan oleh masyarakat sudah lama dipublikasikan melalui penjualan hasil produknya. Sehingga apabila dilakukan pendaftaran untuk mendapatkan hak desain industri belum dapat disimpulkan bahwa desainnya dapat dikatakan baru. Selain itu juga desaindesain yang dihasilkan oleh UMKM yang dalam penelitian ini didominasi oleh usaha mikro dan kecil hanya beberapa desain pada produk tertentu saja dapat dikatakan inovatif dan dikatakan memiliki nilai karakteristik khusus atau keunikan tersendiri yang tidak terdapat pada desain produk sejenis.

Bila dilihat dari segi keunggulan kompetitif ini, potensi desain industri yang dihasilkan oleh UMKM yang ada di Kota Pangkalpinang secara umum masih belum begitu kompetitif. Hal itu disebabkan desain produk yang dihasilkan masih sebagian besar hanya memenuhi kebutuhan lokal dan belum banyak pesaing. Karena hanya beberapa desain produk saja yang pelaku usaha mampu menjual dengan harga yang kompetitif dibandingkan dengan desain produk pesaingnya atau memberikan manfaat yang melebihi desain produk pesaingnya. Seperti misalnya desain batik tulis yang dihasilkan dari beberpa kelompok usaha bersama yang ada di Pangkalpinang dan kerajinan pewter.

$$
\text { Sedangkan keunggulan }
$$

komparatif memiliki parameter berupa daya saing dalam nilai karakteristik khusus yang tidak dimiliki pesaing lain. Desain inovatif yang dihasilkan oleh UMKM yang ada di Kota Pangkalpinang masih sedikit yang memiliki nilai karakteristik khusus yang tidak dimiliki oleh UMKM atau pesaing lain. Atau yang memiliki keunikan daya pembeda dibanding desain produk sejenis. Sebagai contoh desain batik tulis yang dihasilkan oleh beberapa kelompok usaha yang ada di Pangkalpinang sangat berbeda keunikan desainnya yang tergantung pada kreatifitas pengembangan atau inovasi desainnya dari waktu ke waktu. Akan tetapi pada batik tulis ini hanya dihasilkan dari sedikit kelompok usaha saja, sehingga belum banyak pesaing. Ada juga desain pada kerajinan pewter. Pada kerajinan pewter ini desainnya masih dimungkinkan ditiru oleh para pengrajin lain dan belum terlalu unik. Desain yang dihasilkan oleh kerajinan 
pewter ini masih hanya melihat bentukbentuk yang desain nyata yang ada misalnya kapal, mobil, dan lain-lain. Contoh lain misalnya desain meja, kursi, pot dan lain sebagainya dari semen, kayu atau tanah liat yang dibuat bervariasi dibanding desain yang dihasilkan oleh produk sejenis, namun belum menunjukkan suatu keunikan tersendiri, masih begitu sederhana. Desain yang dihasilkan kebanyakan masih umum dibuat oleh UMKM lain, sehingga daya saingnya rendah dan kurang adanya inovasi pada desainnya.

Dari dua indikator di atas yaitu segi keunggulan kompetitif dan keunggulan komparatif, dapat dikatakan bahwa desain industri pada produk yang didesain sendiri oleh pelaku usaha pada UMKM yang ada di Kota Pangkalpinang masih belum memiliki potensi yang diunggulkan sebagai salah satu penyokong perekonomian masyarakat, khususnya di Kota Pangkalpinang.

\section{PENUTUP}

\section{Kesimpulan}

Perlindungan hukum merupakan suatu hal yang harus dilakukan oleh pemerintah dengan dukungan dari segenap masyarakat atau stakeholder. Bila dikaitkan dengan kekayaan intelektual, maka perlindungan hukum pada hal itu sangat dibutuhkan saat ini mengingat Indonesia telah masuk dalam MEA. Kreatifitas pelaku usaha sangat dibutuhkan dalam mempertahankan ekonomi Indonesia khususnya dalam bidang desain industri, sehingga desain industri yang dihasilkan pelaku usaha (UMKM) di Indonesia dapat dilindungi dengan baik. Salah satu tolak ukur yang dapat mendorong perekonomian suatu wilayah adalah berapa banyak kekayaan intelektual yang dilindungi dan dikembangkan sebagai kekayaan dan pertahanan ekonomi suatu wilayah maupun bangsa. Desain pada ekonomi kreatif yang berbasis ilmu pengetahuan yang dihasilkan oleh UMKM di Kota Pangkalpinang belum banyak. Desain yang dihasilkan dari kreatifitas pelaku usaha pada UMKM masih belum dilindungi dengan baik. Hal tersebut dikarenakan desain yang mereka hasilkan masih belum jelas unsur kebaruannya dan belum didaftarkan untuk memperoleh sertifikat desain industri. Secara garis besar terdapat beberapa alasan yang menyebabkan 
pelaku usaha enggan untuk melindungi hasil desain industri pada produknya diantaranya yaitu pelaku usaha tidak mau memonopoli usahanya, waktu pendaftaran yang relatif masih lama menurut pelaku usaha, kesadaran hukum pelaku usaha yang rendah, ketidaktahuan masyarakat akan undang-undang desain industri dan adanya pemahaman masyarakat yang salah dalam memahami perlindungan terhadap desain yang dihasilkannya. Sehingga perlu adanya pembenahan dalam melakukan sosialisasi yang efektif dan berkelanjutan serta pembianaan agar masyarakat dapat terdorong untuk lebih sadar dalam mengamankan asset yang sangat berharga yaitu desain industri hasil ciptaannya.

Potensi desain industri yang dihasilkan oleh UMKM di Kota Pangkalpinang masih kecil. Hasil observasi dilapangan baru ditemukan kurang lebih 12 (dua belas) jenis produk yang dihasilkan dari kreatifitas tangan pelaku usaha pada ekonomi kreatif yang berbasis ilmu pengetahuan-kekayaan intelektual yang merupakan kreatifitas yang dihasilkan dari olah pikir manusia dalam rangka memenuhi kebutuhan dan kesejahteraan hidup manusia-pada UMKM. Terdapat 2 (dua) indikator dalam menyimpulkan potensi dari desain industri ini yaitu segi keunggulan kompetitif dan keunggulan komparatif. Dari dua indikator di atas yaitu segi keunggulan kompetitif dan keunggulan komparatif, dapat dikatakan bahwa desain industri pada produk yang didesain sendiri oleh pelaku usaha pada UMKM yang ada di Kota Pangkalpinang masih belum memiliki potensi yang diunggulkan sebagai salah satu penyokong perekonomian masyarakat, khususnya di Kota Pangkalpinang.

\section{Saran}

Pentingnya peran dan posisi UMKM di Pangkalpinang sebagai salah satu komponen penggerak perekonomian dan perdagangan. Maka, ada beberapa saran yang dapat diberikan dari hasil penelitian ini sebagai berikut:

a. Perlu adanya sosialisasi yang diberikan kepada masyarakat dunia usaha yang lebih efektif.

b. Perlu adanya koordinasi dan merangkul

pelaku 
usaha/stakeholder dalam mengembangkan atau inovasi desain industri secara berkelanjutan, sehingga dapat memetakan potensi UMKM yang memiliki potensi desain yang inovatif.

c. Perlu ditambah program dan dana dari pemerintah yang mendukung pengembangan kreativitas dalam dunia usaha khususnya desain industri.

d. Perlu adanya pembinaan yang berkelanjutan dari pemerintah daerah kepada para pelaku usaha yang telah kreatif mengembangkan desain produknya untuk didorong terus mengembangkan potensi kreativitasnya dalam menghasilkan desain industri yang bermutu dan unik serta membantu mengusahakan perlindungan terhadap desain-desain tersebut.

\section{DAFTAR PUSTAKA}

\section{Adrian Sutedi, Hak Atas Kekayaan Intelektual, Sinar Grafika, Jakarta, 2009.}

Ansori Sinungan, Perlindungan Desain Industri: Tantangan dan Hambatan dalam Praktiknya di Indonesia, Cetakan ke-1, Alimni, Bandung, 2011.
Badan Pengkajian dan Penerapan Teknologi, Hak Kekayaan Intelektual Suatu Panduan di Lingkungan BPPT, Unit Pengelola HKI-BPPT, Jakarta, 2011.

Bahder Johan Nasution, Metode Penelitian Ilmu Hukum, CV. Mandar Maju, Bandung, 2008.

Hendry Soelistyo, Hak Kekayaan Intelektual: Konsep, Opini dan Aktualisasi, Penaku, Jakarta, 2014.

Jimly Asshiddiqie dan M. Ali Saa'at, Teori Hans Kelsen Tentang Hukum, Cetakan Ketiga, Konstitusi Press, Jakarta, 2012.

Kholis Roisah, Konsep Hukum Hak Kekayaan Intelektual, Setara Press, Jatim, 2015.

Muhamad Djumhana dan Djubaedillah, Hak Milik Intelektual Sejarah, Teori dan Prakteknya di Indonesia, Citra Aditya Bakti, Bandung, 2003.

Rahmi Jened Parinduri Nasution, Interface Hukum Kekayaan Intelektual dan Hukum Persaingan Usaha (Penyalahgunaan HKI), Rajawali Press, Jakarta, 2013.

Sudargo Gautama dan Rizawanto Winata, Hak atas Kekayaan Intelektual (HAKI)Peraturan Baru Desain Industri, Cetakan Kedua yang Direvisi dan Ditambah, Citra Aditya Bakti, Bandung, 2004.

Sudarmanto, KI \& HKI Serta Implementasinya bagi Indonesia, Elex Media Komputindo, Jakarta, 2012. 
Sudaryat, dkk., Hak Kekayaan Intelektual, Cetakan I, Oase Media, Bandung, 2010.

Tim Lindsey, dkk. (Editor), Hak Kekayaan Intelektual Suatu Pengantar, Alumni, Bandung, 2011.

Undang-Undang Republik Indonesia Nomor 14 Tahun 2001 tentang Paten.

Undang-Undang Republik Indonesia Nomor 31 Tahun 2000 tentang Desain Industri.

Ekonomi Kreatif, http://arifh.blogdetik.com/ekonomikreatif/, diakses tanggal 29 April 2015.

http://tesishukum.com/pengertianperlindungan-hukum-menurut-paraahli/ diunduh pada tanggal 1 Agustus 2016.

Otjih Sewandarijatun, Siapkah kita Menghadapi Masyarakat Ekonomi Asean, http://leuserantara.com/ artikel-siapkah-kita-menghadapimasyarakat-ekonomi-asean-mea-

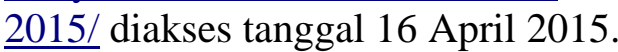

Pengertian Ekonomi Kreatif dan Industri Kreatif Menurut Para Ahli, http://www.fundbisnis.com/pengertia n-ekonomi-kreatif-dan-industrikreatif-menurut-para-ahli/html, diakses tanggal 29 April 2015.

Peran Pemerintah dalam Perekonomian dan Sistem Bisnis, http://akmalfarantfaiz53.blogspot.co m/2013/06/artikel-peran-pemerintahdalam.html, diakses tanggal 29 April 2015. 